\title{
Qualitative Circulation Space Application at the 'Tunjungan Plaza' Shopping Mall in Surabaya
}

\author{
Sriti Mayang Sari, ${ }^{a}$ M. Dwi Marianto, ${ }^{\mathrm{b}}$ Suastiwi ${ }^{\mathrm{c}}$ \\ aPetra Christian University, Siwalankerto 121-131, Surabaya 60236, Indonesia \\ b,c Indonesia Institute of the Arts, Suryodiningratan 8, Yogyakarta 55141, Indonesia. \\ email: srtiti@petra.ac.id
}

\begin{abstract}
Public circulation space is an interior element that organizes and connects the different parts of a shopping mall together. As such the circulation space is partly defined by the different accommodation of shops, anchor stores, catering and leisure facilities. In considering the organizational framework to be established by the public circulation space the objectives can be separately identified into functional and qualitative requirements. The functional requirements are essential primary planning considerations and the qualitative requirements are recommended secondary planning and more detailed design considerations. The goal of this research is to identify the qualitative circulation requirements at Tunjungan Plaza, Surabaya, as one of the biggest shopping mall in East Java. As a result of the field identification will create some recommendations for the qualitative circulation requirement that suitable for the shopping mall visitor.
\end{abstract}

Keywords: Qualitative, Circulation Space, Shopping Mall

\section{INTRODUCTION}

The development of shopping centre (shopping mall, plaza) or mall has spread out in the big cities in Indonesia. This development is counted vast as the dynamic growth of business world and economic. The development of mall function and facilities is outstanding. Nowadays the function of malls in Indonesia is not only as department stores, but also entertainment facilities which is getting more dominant, such as movie theatre, food court, kids playground, exhibition area, fitness centre area, meeting room area, and even nursery room area and church.

Interior Design of a shopping mall is designed with certain criteria which is relevant with the definition of shopping space, including the function, shape, size, pattern, also the feel of the space. Function is the most fundamental part of an interior designing, because functional rooms make activities within become easier, more comfortable, and fun. The suitable function will increase the value of the room. Function in interior design usually relates to the dimensional matters and things that are measurable such as mall circulation to create a dynamic feel when visitors, whether individually or in group, walking together in a mall, or passing by watching the shop fronts, and so on.

However, mall architecture and interior as a built environment which is designed as an 
area for visitors to move, do activities, and interact within space, covers more than just dimensional functions. Culture and daily routine indirectly affect the feel of shopping in a mall. Studying the visitor activities who come alone or in group is very interesting. For example, when they are interacting with the shop interior, doing window shopping, and eating in a food court.

\section{MATERIALS AND METHOD}

In general, mall is a closed multi floor building with eye catching window shopping and interior, arrangement good air circulation so the visitor can do their activities comfortably. Mall filled by a variety of retail or shops in one solid structure, independent vendor or branded stores melting pot. Between one store and others connected by circulation's line with the aim of facilitating the visitors to walk from one shops to others (Sari, 2010:52-61).

\section{Circulation of Shopping Mall}

The function of space circulation in shopping mall is to connect interior and exterior spaces together on building. The pathways of this public circulation is an element that organizing and combining different parts in shopping mall. Public circulation path is determined by different accommodation facilities, such as stores, anchor tenant, catering, food court, and entertainment facilities. Thus space or circulation path is forming the planning structure and layout in shopping mall. Vertical and horizontal circulation is applied in a shopping mall to help visitor reach stores and others facilities easily.

Corridor, bridge and atrium are modes of horizontal circulation generally applied in a shopping centre (mall). Their main function is to cater and distribute consumers to all parts of the shopping centre (mall) and to shops and stores there). Type of corridor that is commonly applied in a shopping centre (mall) is single loaded corridor of 3 metres wide or even more. It is provided to ease consumers' circulation so that they are able to enjoy the shop frontages, undisturbed by those who are just passing by ( Aditya \& Suharnoko, 2006).

Escalator, lift is a vertical circulation that are commonly used in shopping mall. The presence of escalator and lift is to help visitors to access stores or tenants and also they can visually direct see the goods that offered.The form of circulation space of shopping mall should be well planned, because it will affect to the success of the building. Many important functional consideration to be aware, such as the widespread of circulation space have to accommodate the visitors during the crowded time. As well as influencing the function of the shopping centre, the circulation space will also establish the character of the centre, thereby having a significant influence over the visitors' qualitative memories of the place. This qualitative aspect is especially important in an age when providing customers with memorable experiences is all-important (Coleman, 2006). 


\section{Functional and Qualitative Requirements}

According Coleman (2006), in considering the organizational framework to be established by the public circulation space the objectives can be separately identified into functional and qualitative requirements. The functional requirements are essential primary planning considerations and the qualitative requirements are recommended (nice to have) secondary planning and more detailed design considerations. The functional requirements represent the basic and well-established general rules of shopping centre planning. They are essential considerations common to all shopping formats and were referred to earlier. The qualitative requirements tend towards the consideration of the use of the centre from the viewpoint of the customer and are recommended considerations that can make the difference between one centre and another.

The qualitative requirement of the circulation of public space will be discussed in this research. Because of the qualitative considerations which generally give character in space and help make the facility more memorable and enjoyable. The following summary of the qualitative consideration of Coleman that used as parameter to examine the public space circulation at 'Tunjungan Plaza' shopping mall, Surabaya. The qualitative considerations which generally give character to a place and help make the facility more memorable and enjoyable.

Public circulation space qualitative requirements: secondary-planning considerations (recommended):

1. Consider giving different areas or individual lengths of circulation space a separate recognizable identity.

2. Establish a clear hierarchy between the different circulation spaces which correspond to the relative importance of the function of the space.

3. Provide protection from the weather.

4. Form a comfortable environment which will be an improvement on the external ambient temperature.

5. Provide a chilled environment in summer.

6. Provide a heated environment in winter.

7. Establish a sense of well-being from a well-made and maintained environment.

8. Provide a positive memorable experience (combining functional and qualitative considerations):

- general quality and proportion of space.

- form the space to facilitate the occurrence of informal social and civic uses to include:

- identifiable meeting places

- space for seating to allow visitors to enjoy the place and watch the activity

- space for occasional gatherings, events, performances and Christmas displays.

- spontaneous overspill space for tables and chairs to allow street cafés and dining.

- generally encourage the visitor to dwell and experience the place:

- by inclusion of the above informal spaces. 
- provide a quality of detailing, finishes and general workmanship which can withstand scrutiny.

- incorporate aspects of craftsmanship integrated into the finishes (decorative plaques, motifs, decorations)

- incorporate elements of artwork (stand alone and integrated pieces)

- provide civic elements (clocks, water sculptures and other features).

All the facilities, if well considered, will encourage the visitor to engage with the place, enhance their experience and encourage the use of the shopping facility in preference to another.

\section{Aims}

The goal of this research is to identify the qualitative circulation requirements at Tunjungan Plaza, Surabaya, as one of the biggest shopping mall in East Java. As a result of the field identification will create some recommendations for the qualitative circulation requirement that suitable for the shopping mall visitor.

\section{Methodology}

This research employs qualitative method for analyses the problems. The steps of the research are adopted from Creswell (2009) as bellows:

- Choosing the research object. There are some important consideration to decide which mall to be chosen as the research object, such as the evolution of Indonesian shopping mall which develops fast, both in function aspect and also in the site area. 'Tunjungan Plaza' Shopping Mall in Surabaya is chosen as the research object because it is the biggest mall in Eastern Indonesia, located in the centre of the city, the most popular, and it has a high rate of visitor.

- $\quad$ Literature study is done by journals, books, and documents related to shopping mall, circulation, and visitor activities inside a mall.

- Qualitative observation is done by doing real observation in 'Tunjungan Plaza' Shopping Mall Surabaya to watch the shopping mall circulation and mall visitors' activities in the circulation area. The observation is reported by notes and photos documentation.

- Visitor interview to random teenage, adult, and parents to show them a view in qualitative circulation in a shopping mall. This interview is done both in the low and high rates of visitor.

- Data interpretation and analysis. The collected data is analyzed using the Coleman's Public circulation space qualitative requirements parameter, followed be the making of qualitative circulation requirement statement which is suitable to Surabaya mall visitors.

\section{DISCUSSION}

The emergence of modern shopping mall in Surabaya was begun by Tunjungan Plaza which is established in 1986 and until today is still a favourite. Before Tunjungan Plaza, some other malls have been established in Surabaya such as Delta Plaza and Surabaya Mall. However, these malls is not as modern and big as Tunjungan Plaza. After Tunjungan Plaza, the establishment of some newer shopping malls raises. There are more than 26 malls in Surabaya nowadays, spreading in five regions: central, north, south, west and east Surabaya. The establishment of shopping mall in Surabaya is not 
only in the centre of city, but also in all part of it.

Tunjungan Plaza has four main buildings which are interconnected (Tunjungan Plaza 1/ East Plaza, Tunjungan Plaza 3/Centre Plaza, Tunjungan Plaza 2/ Lifestyle Plaza and Tunjungan Plaza 4/West Plaza). Tunjungan Plaza is strategically located in the city centre of Surabaya. As part of Tunjungan City superblock which consists of not only a shopping centre, but also a condominium, five star hotel and office tower, Tunjungan Plaza has become the largest shopping centre

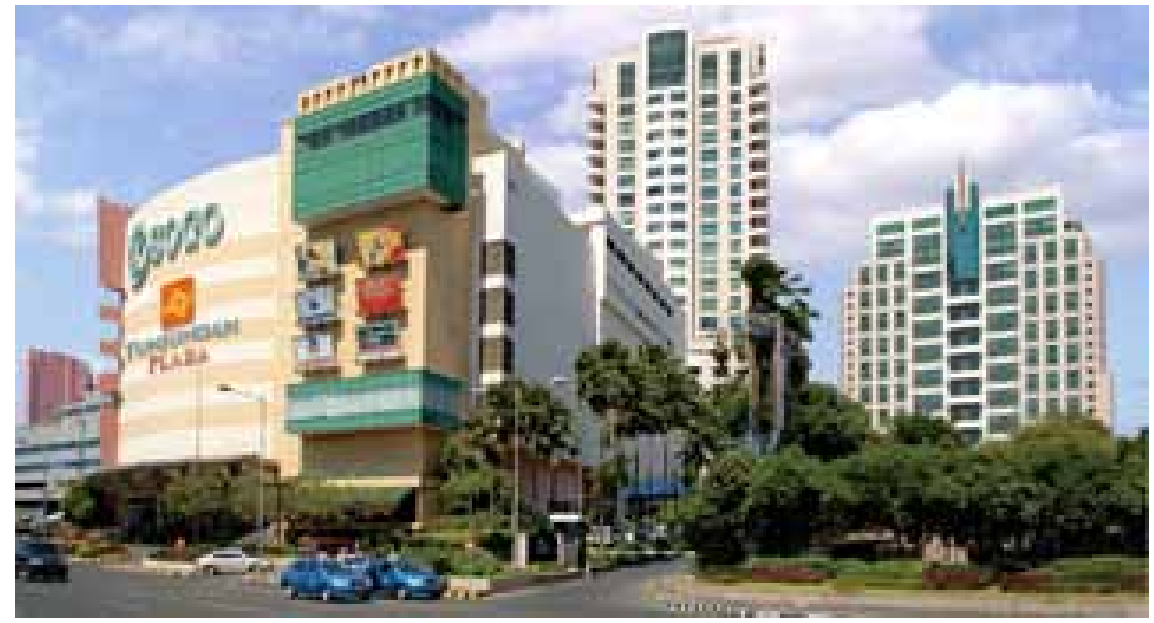

Figure 1. Superblock Tunjungan City. Tunjungan City is the first Superblock in Indonesia and consists of Tunjungan Plaza, Mandiri Office Tower, Condominium Regensi and the five-star Sheraton Surabaya Hotel and Towers (http://pakuwon.com/Property-Portfolio).

There are some factors to succeed Tunjungan Plaza as a shopping mall like its location, brand name, and the timing of establishment. Tunjungan Plaza is located in the center of Surabaya, Tunjungan Plaza's brand name is so popular in East Java society, and Tunjungan Plaza is established when the trend of modern shopping malls began in US and Asia [6].

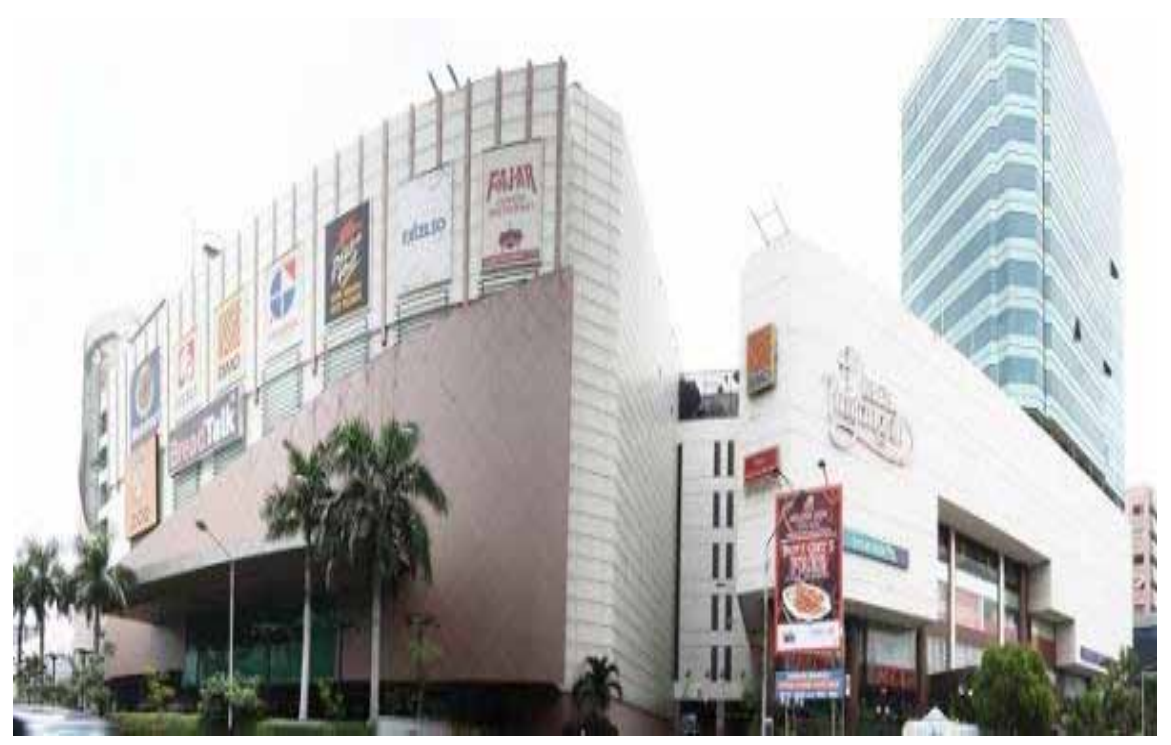

Figure 2. Shopping Mall 'Tunjungan Plaza' (http://tunjunganplaza.com/front/aboutus). 
Tunjungan Plaza was established in 1986. At that time it was the first modern shopping center in Surabaya which operated for 12 hours every day. Nowadays it has the total area of $125,000 \mathrm{M} 2$. It is the favourite shopping destination and leisure place for both locals and foreigners in Surabaya. It has also become an icon that tourists and visitors should come and see. Supported by anchor tenants such as SOGO, Matahari Department Store, Gramedia, Tunjungan 21, Cinema XXI, Ace Hardware, Informa, Hero Supermarket, Amazone and Celebrity Fitness, hundreds of local brand and famous international brand tenants, a huge Convention Center and two main atriums, Tunjungan Plaza has become a complete shopping destination and has offered an ultimate shopping excitement to its visitors [8].

To improve the objectivity of this research, researcher put herself as a visitor while exploring and observing facilities related to circulation in TP. The results are pictures of circulation facilities, interview data, and 'public circulation space qualitative requirements' checklist (see: table 1 ).

Table 1. Parameter for public circulation space qualitative requirements: secondary planning considerations (recommended)

\begin{tabular}{|c|c|c|c|c|}
\hline Considerations & 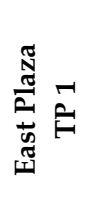 & 蛋 & 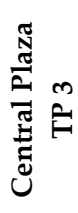 & 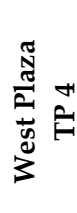 \\
\hline $\begin{array}{l}\text { Consider giving different areas or individual lengths of circulation } \\
\text { space a separate recognizable identity }\end{array}$ & - & - & - & - \\
\hline $\begin{array}{l}\text { Establish a clear hierarchy between the different circulation spaces } \\
\text { which correspond to the relative importance of the function of the space }\end{array}$ & - & - & - & - \\
\hline Provide protection from the weather & - & - & - & - \\
\hline $\begin{array}{l}\text { Form a comfortable environment which will be an improvement on the } \\
\text { external ambient temperature }\end{array}$ & - & - & - & - \\
\hline Provide a chilled environment in summer & - & - & - & . \\
\hline Provide a heated environment in winter & - & - & - & - \\
\hline $\begin{array}{l}\text { Establish a sense of well-being from a well-made and maintained } \\
\text { environment }\end{array}$ & - & - & - & - \\
\hline \multicolumn{5}{|l|}{$\begin{array}{l}\text { Provide a positive memorable experience (combining functional and } \\
\text { qualitative considerations): }\end{array}$} \\
\hline - general quality and proportion of space & - & - & o & - \\
\hline \multicolumn{5}{|l|}{$\begin{array}{l}\text { - form the space to facilitate the occurrence of informal social and } \\
\text { civic uses to include: }\end{array}$} \\
\hline - $\quad$ identifiable meeting places & . & . & . & - \\
\hline $\begin{array}{l}\text { - } \quad \text { space for seating to allow visitors to enjoy the place and watch } \\
\text { the activity }\end{array}$ & - & - & - & - \\
\hline $\begin{array}{l}\text { - } \quad \text { space for occasional gatherings, events, performances and } \\
\text { Christmas displays }\end{array}$ & - & - & - & - \\
\hline $\begin{array}{l}\text { - } \quad \text { spontaneous overspill space for tables and chairs to allow street } \\
\text { cafés and dining }\end{array}$ & $\cdot$ & - & - & - \\
\hline
\end{tabular}




\begin{tabular}{|c|c|c|c|c|}
\hline - generally encourage the visitor to dwell and experience the place: & & & & \\
\hline$-\quad$ by inclusion of the above informal spaces & - & - & - & - \\
\hline$-\quad \begin{array}{l}\text { provide a quality of detailing, finishes and general } \\
\text { workmanship which can withstand scrutiny }\end{array}$ & - & - & - & - \\
\hline $\begin{array}{l}\text { incorporate aspects of craftsmanship integrated into the } \\
\text { finishes (decorative plaques, motifs, decoration) }\end{array}$ & - & - & - & - \\
\hline $\begin{array}{l}\text { incorporate elements of artwork (stand alone and integrated } \\
\text { pieces) }\end{array}$ & - & - & - & - \\
\hline $\begin{array}{l}\text { provide civic elements (clocks, water sculptures and other } \\
\text { features) }\end{array}$ & - & - & - & - \\
\hline
\end{tabular}

Notes:

- : applied the parameter $\quad$ o : applied, but not the same as the parameter $\quad$ - : not applied

Based on the parameter checklist in table 1, it is obtained that no area from East Plaza (Tunjungan Plaza 1) to West Plaza (Tunjungan Plaza 4) apply those parameter aspect completely. Thus, discussion will be focused on the implementation of aspects which are not suitable with the parameter and not apply those aspects in Tunjungan Plaza.

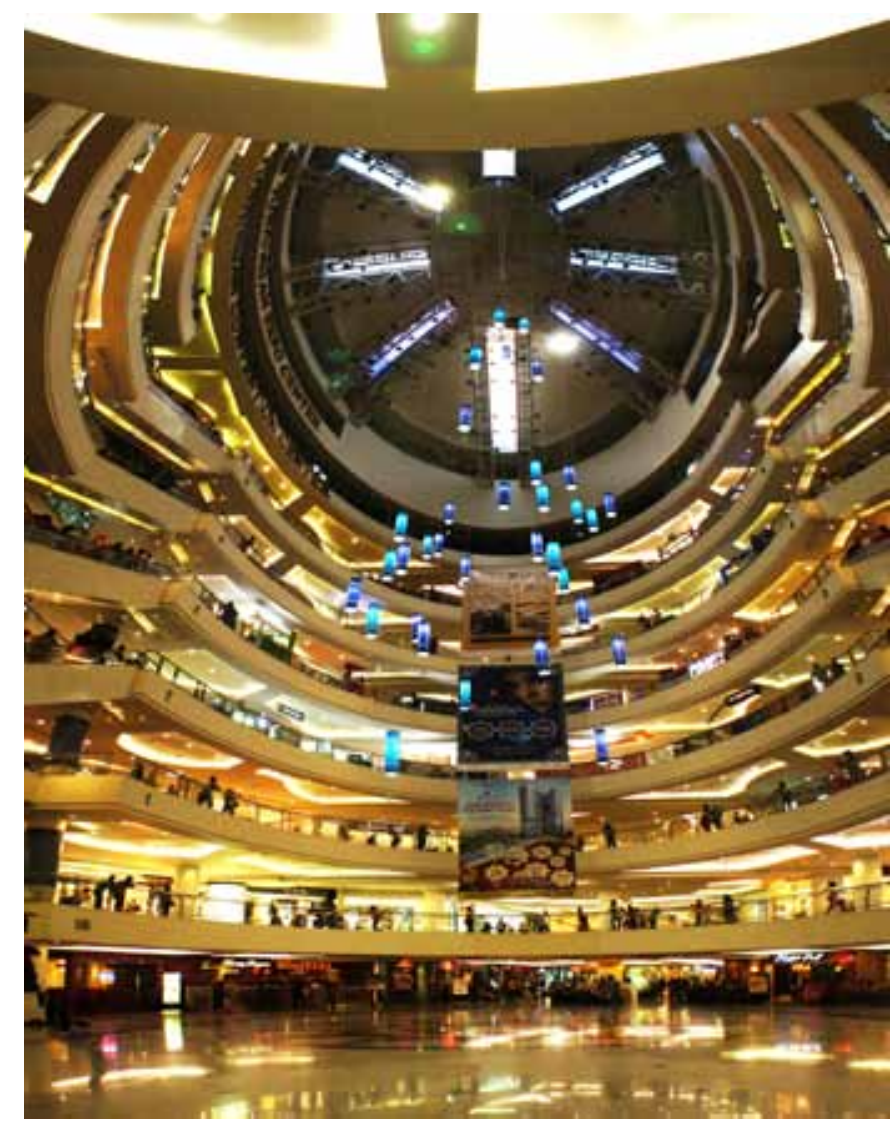

Figure 3. Interior at the atrium of Tunjungan Plaza 3, an area for activities such as product exhibitions, promotion, etc. 
Not all parameters can be applied in Tunjungan Plaza shopping mall. For example: Shopping mall should provide a heated environment in winter. It is not necessary to be implemented in Tunjungan Plaza because there is no winter in Indonesia. Tunjungan Plaza uses air conditioning for all areas, and this is one of the aspects that make visitors enjoy staying in this mall.There are some important qualitative requirements aspect which can give a positive memorable experience, but it is not applied or applied but not maximal. Circulation space quality and proportion aspect shows that there are crowd in Tunjungan Plaza 3 (Central Plaza) in its prime times (weekend, holidays or special events) that minimize visitors comfort in enjoying the mall atmosphere (see: figure 4 \& 5).

It is a fact that Tunjungan Plaza 3 has the highest rates visitors, because it is located between Tunjungan Plaza 1 and Tunjungan Plaza 4, it is also used as the circulation path to the Sheraton Hotel and Condominium. The purpose of Tunjungan Plaza itself is to be part of Tunjungan City Superblock where is consisted of shopping mall, hotel, condominium and office tower, which lead this mall into a crowd both in the weekdays and the weekends.

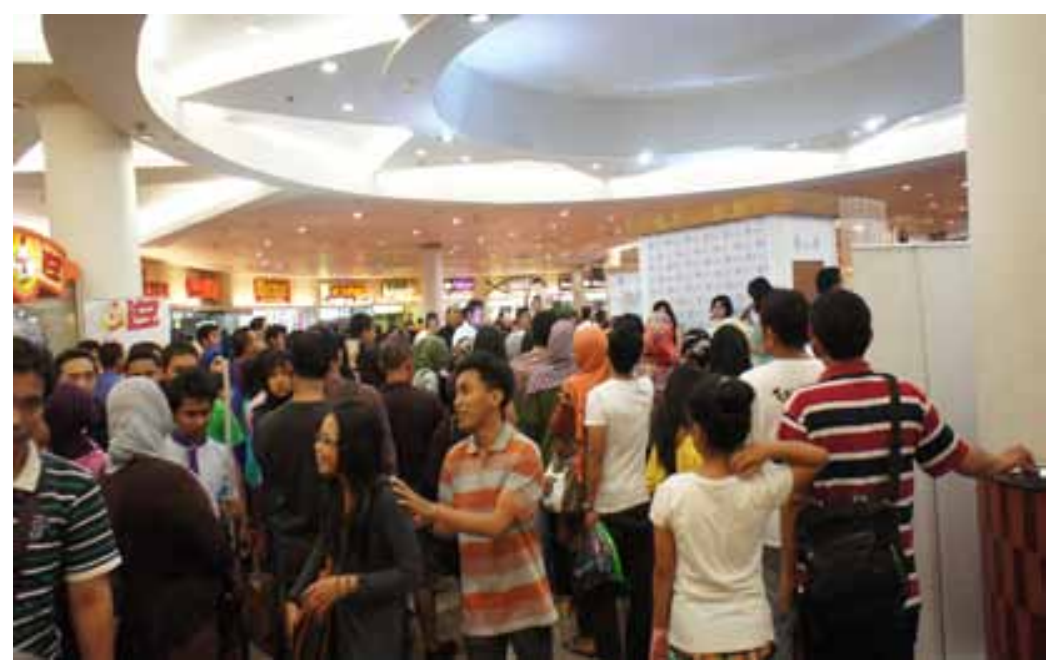

Figure 4. Visitor crowd in Central Plaza/Tunjungan Plaza 3

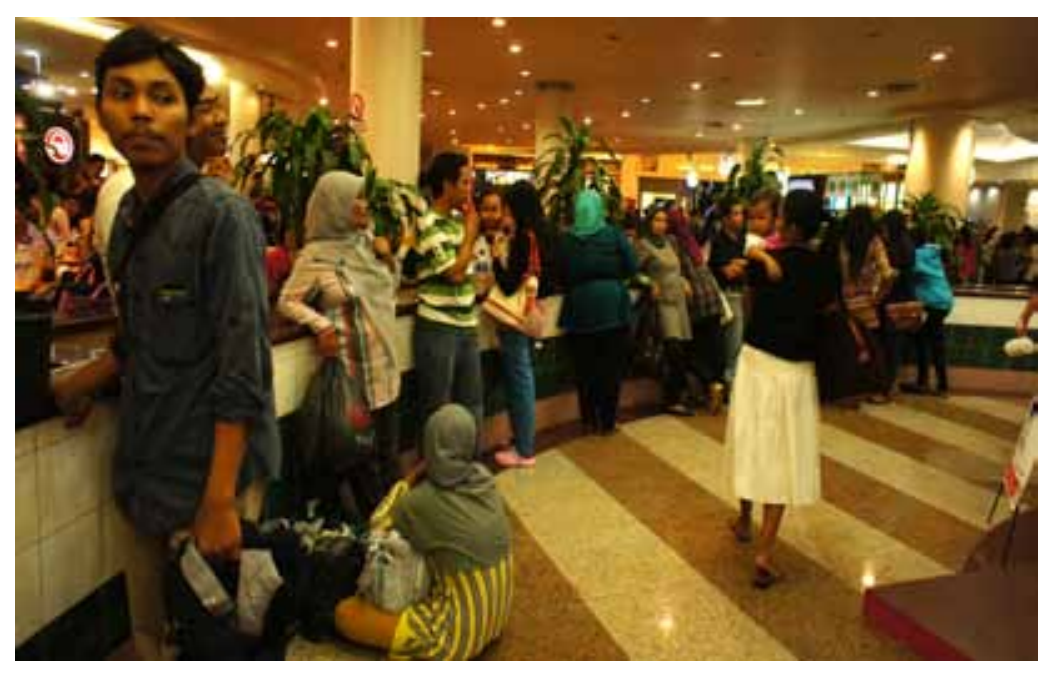

Figure 5. Visitors in Tunjungan Plaza 3 take a rest standing and sitting on the circulation area while enjoying the atmosphere of the mall. This situation annoys other visitors who need to pass. 
Another aspect which is also important and it is not available in all other Tunjungan Plaza areas are the availability to enjoy shopping mall atmosphere and visitor activities. Since the absence of sitting rooms, there are many visitors sitting on the breezeway in circulation path. It disturbs visitors who need to pass because the circulation path becomes narrow and create a visitor crowd (see: figure 6 and 7). It happens especially in Tunjungan Plaza 1 and 3, while it doesn't happen in Tunjungan Plaza 2 nor Tunjungan Plaza 4. It doesn't happen in Tunjungan Plaza 2 because this plaza is destined for lifestyle plaza only where cafés and restaurants located. It also doesn't happen in Tunjungan Plaza 4 because it is destined for high-end segment where its interior atmosphere makes non concerned visitors unwilling to come.

Related to the fact of no sitting room or sitting area in Tunjungan Plaza 1 and Tunjungan Plaza 3, and based on the visitor interview result, it is shown that they need these kind of sitting facilities for free. When they are waiting for their girlfriends, wives, or friends, they do not have to wait in a cafe or restaurant. They also want to be facilitated with the public sitting area, so when they have to wait, or meet a friend up, or just relaxing in a mall, they can just sit and enjoying the mall atmosphere. For some visitors, a mall atmosphere alone is already an interesting entertainment.

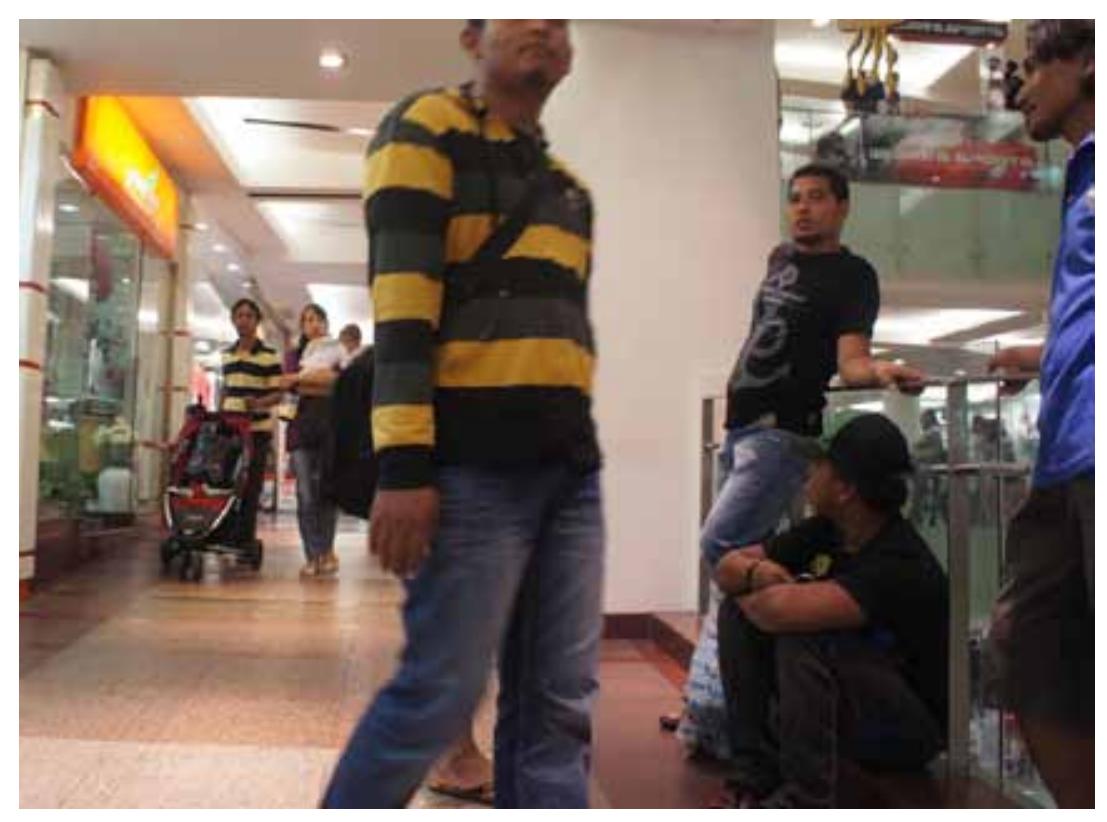

Figure 6. Visitors sitting in circulation path at Tunjungan Plaza 3 


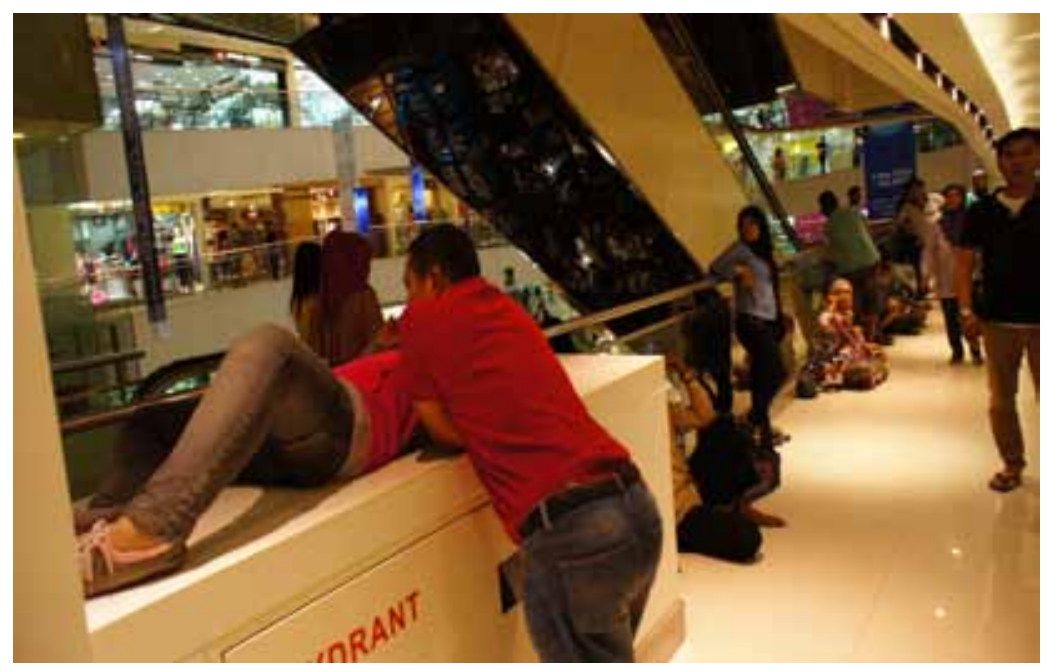

Figure 7. Visitors are relaxing in circulation area at Tunjungan Plaza 1. Some of them sit while talking each other and seeing around the mall, and the others laying on the hydrant area.

Parametrical aspects which give visitors new experiences and they need to stay longer in shopping mall relates to decorations, artworks, and other elements. Interior finishing aspect which is related to art work is only implemented in Tunjungan Plaza 4 , as a painting at the ceiling along the corridor in restaurant areas and void (see: figure 8 and 9). While on the floor, as a circulation area, there is flooring patterns creating circulation path. For decorative aspect, Tunjungan Plaza management doesn't decorate permanently its shopping mall because automatically it has been created by the existence of many kind of window display at shop-front. Temporary decoration is usually created by Tunjungan Plaza management with special themes relevant to on going events.

This condition in fact has made the mall visitors happy, according to their opinion the atmosphere has become less monotonous, and this condition has become one of their reasons visiting Tunjungan Plaza.

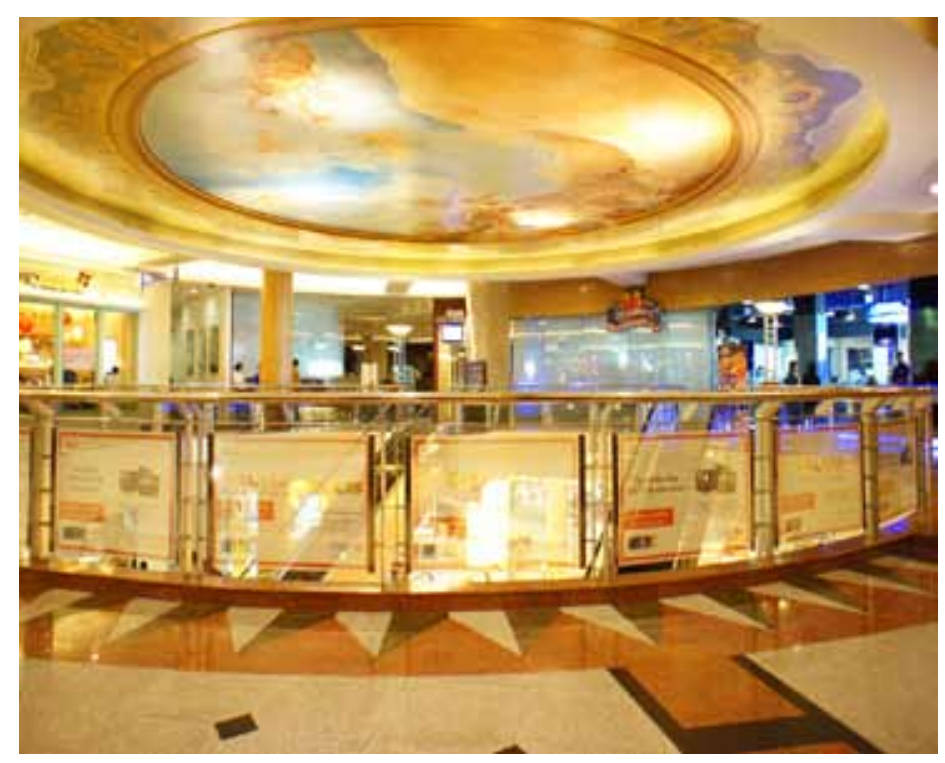

Figure 8. Artwork at the ceiling of Tunjungan Plaza 4 


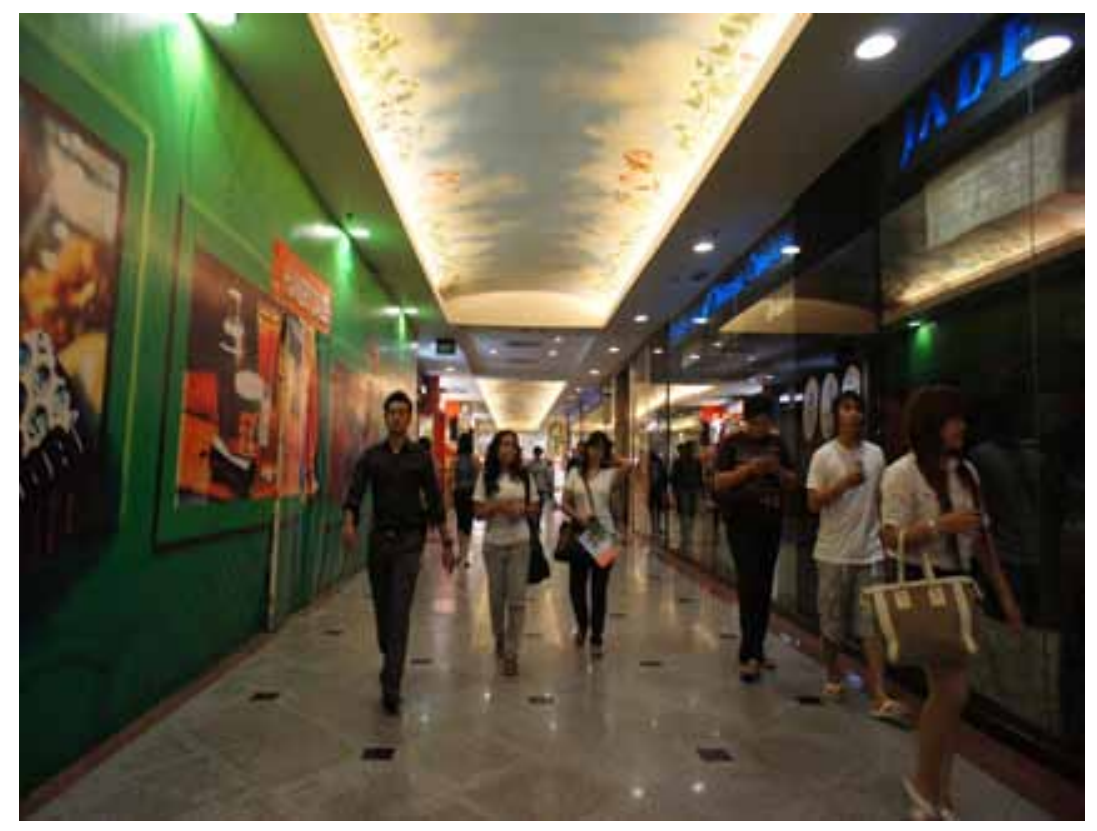

Figure 9. Artwork at the ceiling of Tunjungan Plaza 4

\section{CONCLUSION}

Conclusion of this research is that Tunjungan Plaza has implemented public circulation space qualitative requirements, even though not all parametrical aspects has not been implemented. Aspects which is related to artworks, sculptures, and permanent decoration can be ignored, because the spatial atmosphere has been created by the existence of window display in the shop-fronts. Besides, the existence of temporary decorations has supported the atmosphere of shopping mall which is always change dynamically. Recommendation for public circulation space qualitative requirements which should be considered is the availability of public sitting facility in circulation areas so it can make visitor enjoy the atmosphere of shopping mall.

Recommendation for the next research is to follow up the research on circulation in Tunjungan Plaza shopping mall with phenomenological approach. By this approach, it can be gained visitor's new experience in interactions with space, and this experiences will be useful for designing shopping mall based on visitor needs. The same parameter can be applied in the other shopping malls the big cities in Indonesia, so that it can be found reliable shopping mall parameter.

\section{REFERENCES}

Sari, M.S. (2010). Sejarah Evolusi Shopping Mall. Journal Dimensi Interior, Yuli, A. S., Aditya, F., \& Suharnoko,W. (2006). Indonesia Shopping Center. Jakarta: PT. Griya Asri Prima.

Coleman, P. (2006). Shopping Environments Evolution, Planning and Design. Burlington: Architectural Press.

Creswell, J.W. (2009). Research Design: Qualitative, Quantitative, and Mixed Methods Approaches ( $3^{\text {th }}$ ed.). Thousand Oaks California: Sage Pub.

Ishananto, O. (2010). Mal Surga Tanpa Tuhan Ruang Tanpa Waktu. Surabaya: Jaring Pena. 


\section{ONLINE RESOURCES}

PT Pakuwon Jati TBK http://pakuwon.com/Property-Portfolio.

Tunjungan Plaza, 2013, http://tunjunganplaza.com/.

Tunjungan Plaza, 2013, http://tunjunganplaza.com/front/aboutus. 